sativa and $M$. falcata and their history in East Anglia" and shows that $M$. sylvestris is of hybrid origin. Other articles include "The Adventive Flora of the Port of Bristol" by C. I. Sandwith, "Plant Nomenclature" by Dr. Sprague, and a well-illustrated account of environmental adaptation in various sand dune plants at Braunton Burrows by Dr. F. R. E. Wright.

\section{Australian Entomology}

INTEREST in the remarkable insect fauna of Australia began to be taken soon after Capt. Cook reached the continent in 1770 . There has since arisen an increasing number of writings on Australian insect life. Of late, the stimulus given by applied entomology has led to a great and important literature on the insect pests of the economic animals and plants of the continent. In September 1932, a "Bibliography of Australian Entomology, 1775-1930", by Mr. Anthony Musgrave, was published by the Royal Zoological Society of New South Wales. In his capacity as entomologist to the Australian Museum, Sydney, Mr. Musgrave has listed the title of every known book, memoir and article bearing upon the subject. These are arranged under the authors' names, which are set out alphabetically. A feature of special interest is the series of biographical notes on many of the writers and collectors who have helped to build up our knowledge of Australian entomology. In the production of this bibliography, which runs to 380 closely printed pages, both the author and the Society have conferred a boon on entomologists throughout the world.

\section{Hydrographical Observations from Danish Light-Vessels}

THE recently published "Mean Values of Observations from Danish Light-Vessels" is a pamphlet issued as a special reprint from the Nautical Meteorological Annual, 1932, of the Danish Meteorological Institute. There are numerous tables summarising observations made at Danish light-vessels, such as the salinity at 8 a.m. of the sea-water at the surface and at various depths down to the ocean bottom, frequencies of horizontal visibility of the atmosphere between certain limits in miles, and frequency of ocean currents of various velocities, at different depths of the ocean. These are all long-period averages, mostly referring to $1901-30$ or $1903-30$, but for sea surface temperature going back to 1881 , and for visibility beginning only in 1918, when the modern system of measuring visibility was introduced, and extending only to 1927 . This is clearly not a work for the ordinary student of meteorological literature, but one for the specialist in hydrographic work and for the sailor, and even to those it must be mainly a work of reference. The number of individual observations on which it is based is very large, and the statistical value of the averages is proportionately great.

\section{Revision of Ordnance Maps}

IN the report of the Progress of the Ordnance Survey for the year 1932-33 (London: H.M.
Stationery Office, 1933. 3s. 6d. net), attention is directed to the difficulties and delay in revision of the sheets owing to financial restrictions. The reduced staff available for field work on large-scale plans means that revision has to be limited, more and more, to areas completely altered or built over since the last edition of the sheet. Field work thus tends to become original survey and the time needed for each sheet increases. While the yearly output of 25-in. plans was more than two thousand in 1923, it has now fallen to about seven hundred. In the earlier year the number of man-days spent in the field upon the revision of one 25-in. sheet was about eleven; it is now about fifty-two. The delay is thus progressive as time goes on, and has already become very serious. Since the revision for the one-inch sheet is based on large-scale plans, the new edition of small-scale maps is seriously impeded. Whereas in 1913 a one-inch reviser could do 96 square miles per month in open country or 40 square miles in close country, he can now do only 18 per month in country round London. Nevertheless, the new relief edition of the one-inch map is making steady if slow progress.

\section{Water Flow of the Nile}

Two further volumes of the Egyptian Government's work on the Nile Basin have been published ("The Nile Basin". By H. E. Hurst and P. Phillips. Vols. 3 and 4. Cairo: Government Press. 10s. each). Vol. 3 deals with the gauge readings of the Nile and its tributaries taken at about a hundred stations between El Leisi, a few miles above Cairo, to stations on Lake Victoria and Lake Albert. Most of the data begin within this century, but it is of interest to note that on Roda Island the Nile levels have been recorded each year since the Arab conquest of Egypt. Records of other Arab nilometres are also known but are of little value as their relation to present levels cannot be determined. Vol. 4 records ten-day and mean monthly discharges of the Nile and tributaries at about forty stations, which have been computed in various ways.

\section{The 'Iconoscope' for Television}

AN article under this title appeared in Nature of October 21, p. 648. A paper by Dr. V. K. Zworykin has now appeared in Great Britain $(J$. Inst. Elect. Eng., No. 432). He describes clearly the theory, characteristics and mode of operation of his system, which has now reached the commercial stage. The device used for the registration of the image is called an 'iconoscope'. It consists of a vacuum tube, an electron-emitting 'gun' and a photo-sensitive surface of a unique type. This surface is scanned by an electron beam from the gun which serves as a type of inertialess commutator. The principle of operation permits the storing of energy and very largely increases the output as compared with the ordinary types of television scanners. The reproduction of the image is accomplished by another cathode ray tube with a fluorescent screen called the 'kinescope'. It modulates the impulses from the 
electric beam and this in turn is transformed by the fluorescent screen into variations of light. The scanning is linear and is synchronised at the end of each line, the impulses being transmitted through the same channel as the picture signal. The whole system is completely automatic and is almost as easy to operate as an ordinary radio receiver. The practical details have been all worked out and it looks as if a high grade television transmission set of this type will soon be on the market.

\section{Glass Windows and Ventilation Engineering}

IT is well known that the windows of houses exposed to the sun's rays act like heat traps. They permit most of the radiant energy from the sun to pass into the building but block the low temperature radiation from inside surfaces passing out. Science Service has issued a report of results obtained by research physicists of the American Society of Heating and Ventilating Engineers in their laboratories. Formerly it was thought that glass absorbed only about ten per cent of radiation at low temperatures. The experiments show that a temperature of $550^{\circ} \mathrm{F}$. must be reached before any appreciable amount of the radiation passes through plate glass. Even at $1,000^{\circ} \mathrm{F}$., only a small amount passes through. Glass obviously acts as a very efficient heat trap and this has to be taken into account by the ventilating engineer. In many modern buildings, a side built almost entirely of glass is exposed to the sun's maximum radiation. On a hot summer day, the glass permits the heat from the sun to enter and practically none of it escapes. Indoors, therefore, it becomes unbearably hot. The cost of keeping a building of this nature cool is practically prohibitive. Awnings which deflect the light and are hung outside the windows are perhaps the most efficient. Shades and blinds are of little value as the heat passes through the glass, heats the blind and is convected upwards, thus heating the room. Tests proved that there is no practical difference in efficiency between clear and coloured glass.

\section{Sorting Foods by Reflection of Light}

IT seems that the sorting out of foods by the reflection of light will soon be used in regular commercial practice. It is certainly quite feasible for sorting out foods the quality or maturity of which depends on their colour. Science Service has issued a description of a bean elevator that sorts out white pea beans by means of a photoelectric tube. The device is in use in Lowell, Michigan, and it is said that the plant could be adapted for the sorting of peanuts, coffee, almonds and other foods in which colour is the determining factor when making a selection. It is also possible to sort red kidney beans, green peas and other food crops as easily as white beans are now sorted. A battery of a hundred photoelectric cells is used in the Lowell elevator. It operates with such precision that even although the discoloration of the bean is barely discernible to the human eye, it is rejected with high precision. The individual machine is quite small, consisting of a drum with a series of small holes in the rim. Each bean passes in review before a photoelectric cell. The cell accurately measures the reflection of the light from the bean on it. If the light varies, an electric impulse is transmitted to a thyratron tube which permits sufficient current to pass to operate an electromagnet with a trigger-like hammer at one end. Beans not of the proper colour are dislodged from the vacuum drum by the hammer while good white beans pass into a hopper. The sensitivity of the amplifier can be adjusted until practically only white beans pass undisturbed. Each machine can do as much work as six girls hand-picking beans. A similar device might probably be used for sorting out buttons and other coloured objects.

\section{Physical Tables}

VoL. 88 of Smithsonian Miscellaneous Collections constitutes the eighth edition of the "Smithsonian Physical Tables", the first edition of which appeared in 1896. The preparation of the new edition has been carried out by Dr. F. E. Fowle, of the Smithsonian Astrophysical Observatory, who has availed himself of suggestions and data furnished by authorities in the different fields. The volume has been enlarged to nearly 750 pages and it now contains 871 tables and an index of 22 pages. Where necessary a table is preceded by a short account of the laws relating to the subject, adapted from the writings of some authority to which a reference is given. In cases where recent advances have been rapid and fundamental, the tables and introductions have been supplied by a recognised authority, as for example those on the series relations in atomic spectra, which are by Dr. H. N. Russell. In addition there are ample references to further sources of information. The volume will be welcomed by all who have to search for reliable values of physical constants.

\section{Medical Research in South Africa}

THE annual report for 1932 of the South African Institute for Medical Research, Johannesburg, by the director, Sir Spencer Lister, recently received, gives an account of the work, research and routine, conducted during the year. A quantitative study of the blood-complement in man has been commenced, and in pulmonary tuberculosis and leprosy a considerable proportion of the cases tested showed very small amounts or no complement in the blood. An investigation of South African strains of rabies virus was begun, and nearly every case of human rabies investigated was found to have been caused by the bite of the yellow mongoose or genet cat, and not by a dog bite. Antivenomous serum of exceptional potency for the treatment of snake-bite has been prepared by the use of massive doses of venom modified and rendered atoxic by means of formalin, with subsequent concentration of the serum so obtained.

\section{Study of Canadian Coals}

A strikrng feature of Canada's fuel problem is the absence of coal in the central areas where population 